\title{
Pengembangan handout fluida dinamik terintegrasi metakognisi untuk meningkatkan kemampuan aplikasi siswa
}

\author{
Atep Koswara $^{1} *$, M. Mundilarto ${ }^{2}$ \\ ${ }^{1}$ MAN 1 Sumedang. Jalan Raya Tanjungkerta No. 22, Cimalaka Sumedang, 45353, Indonesia \\ ${ }^{2}$ Program Studi Pendidikan Fisika, Program Pascasarjana, Universitas Negeri Yogyakarta. \\ Jalan Colombo No. 1, Karangmalang, Yogyakarta, 55281, Indonesia. \\ * Corresponding Author. Email: atep.physteach@yahoo.com \\ Received: 21 October 2015; Revised: 17 January 2018; Accepted: 3 April 2018
}

\begin{abstract}
Abstrak
Penelitian ini bertujuan untuk mengembangkan handout fluida dinamik terintegrasi metakognisi. Jenis penelitian ini adalah penelitian dan pengembangan. Subyek penelitian ini adalah guru fisika dan siswa kelas XI IPA pada SMAN 8 Yogyakarta dan MAN Laboratorium UIN Yogyakarta. Instrumen yang digunakan berupa lembar penilaian kualitas handout oleh ahli pendidikan fisika dan guru fisika, lembar tanggapan siswa terhadap kualitas handout, tes awal dan tes akhir kemampuan menerapkan prinsip fluida dinamik, lembar tanggapan guru fisika dan siswa terhadap penggunaan handout. Teknik analisis data yang digunakan adalah analisis deskriptif, analisis gain score, dan analisis varians dua jalur. Hasil penilaian ahli dan guru menunjukkan bahwa handout memiliki kualitas yang sangat baik. Hasil uji lapangan menunjukkan bahwa handout memiliki kualitas yang baik menurut tanggapan siswa, penggunaan handout menghasilkan peningkatan kemampuan menerapkan prinsip fluida dinamik siswa SMA dan MA yang signifikan, dan handout sangat praktis digunakan menurut guru fisika SMA dan praktis menurut siswa SMA.
\end{abstract}

Kata kunci: handouts, fluida dinamik, metakognisi, kemampuan aplikatif

\section{Developing handout of fluid dynamics integrated by metacognition to improve application ability of students}

\section{Abstract}

This research aims to develop a handout of fluid dynamics integrated by metacognition. This type of research is research and development. The subjects of this study were a SMA/MA physics teacher and XI IPA grade students at SMAN 8 Yogyakarta and MAN Laboratory UIN Yogyakarta. The instruments used in this study were in the form of quality assessment sheet of teaching materials handout by physics education experts and SMA/MA physics teachers, students response sheet on the quality of teaching materials handout, initial and final test of application competence of the principles of fluid dynamics, and SMA/MA physics teacher and students response sheet on the use of the teaching materials handout. The data analysis technique used in this research was descriptive analysis, analysis of gain score, and two way analysis of variance. The expert and physics teacher assessment results show that the handout developed has a very good quality. Field testing results show that the handout developed has good quality according to student responses, the use of this handout can result significant improvement on the students ability to apply the principles of fluid dynamics at SMAN 8 Yogyakarta and MAN Laboratory UIN Yogyakarta, and the use of the handout is very practical according to SMA physics teacher and practical according to SMA students.

Keywords: handouts, fluid dynamics, metacognition, application ability

How to Cite: Koswara, A., \& Mundilarto, M. (2018). Pengembangan handout fluida dinamik terintegrasi metakognisi untuk meningkatkan kemampuan aplikasi siswa SMA dan MA. Jurnal Inovasi Pendidikan IPA, 4(1), 11-25. doi:http://dx.doi.org/10.21831/jipi.v4i1.6193

http://dx.doi.org/10.21831/jipi.v4i1.6193 


\section{PENDAHULUAN}

Bahan ajar merupakan salah satu hal yang penting dalam pembelajaran di dalam kelas. Bahan ajar dapat dibuat dalam berbagai bentuk sesuai dengan kebutuhan dan karakteristik materi ajar yang akan disajikan. Pembuatan atau pengembangan bahan ajar merupakan bagian dari tanggung jawab guru sebagai pengajar bagi siswa di sekolah.

Berdasarkan hasil observasi di lapangan pada beberapa sekolah, guru fisika di sekolah tidak mengembangkan sendiri bahan ajar tertulis yang disediakan untuk siswa dalam mengikuti kegiatan pembelajaran di kelas. Guru hanya menyampaikan materi pelajaran secara lisan kepada siswa. Guru tidak menggunakan bahan ajar tertulis yang dikembangkan sendiri dalam kegiatan pembelajaran di kelas sehingga kegiatan pembelajaran menjadi memerlukan banyak waktu dan menyulitkan siswa dalam mengikutinya.

Pada tahun ajaran 2013/2014, beberapa Sekolah Menengah Atas (SMA) mulai menerapkan Kurikulum 2013. Pembelajaran fisika harus menyesuaikan dengan Kurikulum 2013. Begitu juga bahan ajar fisika harus menyesuaikan dengan Kurikulum 2013. Guru fisika harus menyiapkan bahan ajar yang sesuai dengan Standar Isi, Kompetensi Inti, dan Kompetensi Dasar yang telah ditetapkan dalam kurikulum.

Berdasarkan hasil pengamatan di lapangan, pada tahun ajaran 2014/2015, buku teks pelajaran Fisika kelas XI MIPA sesuai Kurikulum 2013 yang dikeluarkan penerbit masih sulit ditemukan. Kalaupun ada, harga buku tersebut cukup mahal dan masih kurang sesuai dengan tuntutan kurikulum. Materi yang disajikan tidak bisa dijadikan sarana untuk memfasilitasi siswa dalam mencapai kompetensi dasar atau menguasai materi pokok, khususnya pada materi pokok fluida dinamik. Keadaan tersebut akan menjadikan siswa mengalami kesulitan dalam memiliki bahan ajar fisika untuk mencapai kompetensi.

Pada umumnya siswa masih merasa bahwa pelajaran Fisika merupakan mata pelajaran yang sulit. Hal tersebut terjadi karena fisika memerlukan matematika yang rumit, memiliki materi yang terlalu banyak, bergantung kepada buku teks, abstrak, dan kompleks (Campbell, 2007, pp. 3-4). Adanya anggapan siswa seperti tersebut di atas terhadap mata pelajaran Fisika menimbulkan minat belajar fisika menjadi rendah serta mengakibatkan hasil belajar fisika menjadi rendah pula.
Berdasarkan hasil observasi di lapangan, siswa masih merasa kesulitan mempelajari fisika di sekolah karena dalam fisika terdapat banyak rumus yang cukup sulit untuk memahami dan menerapkannya. Siswa juga sering merasakan kebingungan ketika memilih rumus yang cocok untuk digunakan dalam pemecahan soal atau masalah fisika. Ketika mempelajari contoh penerapan rumus dalam pemecahan soal fisika, siswa dapat memahaminya. Ketika menghadapi soal yang baru, siswa masih sering mengalami kebingungan untuk memecahkannya. Dengan demikian diperlukan upaya yang dapat dijadikan solusi agar siswa tidak mengalami masalah seperti tersebut di atas.

Salah satu alasan mengapa guru fisika perlu mengembangkan bahan ajar, yaitu karena tuntutan pemecahan masalah belajar. Pengembangan atau pengadaan bahan ajar fisika seharusnya turut serta dalam menjawab atau memecahkan masalah kesulitan dalam belajar fisika. Untuk mengatasi kesulitan ini maka perlu dikembangkan bahan ajar fisika yang tepat.

Pada Kurikulum 2013, jenis pengetahuan dalam Kompetensi Inti mata pelajaran Fisika untuk SMA/MA kelas XI IPA meliputi pengetahuan faktual, konseptual, prosedural, dan metakognitif. Salah satu kompetensi pada tingkatan kompetensi mata pelajaran Fisika (muatan fisika) kelas X dan XI peminatan IPA adalah menganalisis konsep, prinsip, dan hukum mekanika, fluida, termodinamika, gelombang, dan optik serta menerapkan metakognisi dalam menjelaskan fenomena alam dan penyelesaian masalah kehidupan. Menerapkan metakognisi merupakan bagian dari kompetensi mata pelajaran Fisika (muatan fisika) yang harus dimiliki oleh siswa.

Metakognisi adalah suatu sistem pengaturan kognisi yang meliputi aksi dan interaksi dari (a) pengetahuan metakognitif, (b) pengalaman metakognitif, (c) tujuan (tugas), dan (d) aksi (strategi) (Flavell, 1979, p. 906). Metakognisi mengacu pada proses mental yang tinggi yang terlibat dalam belajar meliputi mem-buat perencanaan untuk belajar, menggunakan keterampilan dan strategi yang tepat untuk memecahkan masalah, membuat estimasi kerja, dan menyesuaikan tingkat belajar (Coutinho, 2007, p. 40). Metakognisi merupakan penerapan strategi pengetahuan deklaratif, prosedural, dan kondisional untuk mencapai tujuan dan mengatasi masalah (Woolfolk, 2007, p. 267). Istilah metakognisi telah digunakan secara luas dan berlainan, yang perbedaan penggunaannya 


\section{Jurnal Inovasi Pendidikan IPA, 4 (1), 2018 - 13}

Atep Koswara, M. Mundilarto

bertumpu pada dua pengertian, yaitu sebagai (1) pengetahuan tentang kognisi dan (2) pengontrolan, pemonitoran, dan pengaturan proses-proses kognitif (Anderson \& Krathwohl, 2010, p. 64). Metakognisi menunjuk kepada pengetahuan yang dimiliki seseorang tentang operasi-operasi pengetahuan dan bagaimana pengetahuan tersebut dapat digunakan untuk mencapai tujuan belajar (Snowman \& McCown, 2011, p. 266). Dengan demikian, metakognisi adalah pengetahuan seseorang tentang kognisinya dan pengaturan (regulasi) seseorang terhadap prosesproses kognitifnya sebagai fungsi dari umpan balik yang diterima melalui hasil belajar dan berpikirnya untuk mencapai tujuan dan mengatasi masalah.

Dalam metakognisi dibedakan dua bagian komponen, yaitu (1) pengetahuan metakognitif yang berhubungan dengan pengetahuan deklaratif seseorang tentang hubungan antara personal, tugas, dan strategi dan (2) keterampilan metakognitif yang menyangkut kemampuan untuk memonitor, membimbing, mengarahkan, dan mengontrol prilaku belajar dan pemecahan masalah seseorang (Veenman, 2012, p. 21). Dua komponen utama metakognisi terdiri atas beberapa sub komponen, yaitu pengetahuan proses kognitif; perencanaan melakukan tugas; kontrol atas pikiran, belajar, dan pemahaman saat melaksanakan tugas; pengaturan pikiran dengan membuat pengaturan diri yang tepat; pengontrolan pikiran untuk tindakkan yang diharapkan; dan evaluasi atas proses kognitif setelah solusi atas masalah ditemukan (Scott \& Levy, 2013, p. 122). Metakognisi melibatkan tiga tipe pengetahuan, yaitu pengetahuan deklaratif, pengetahuan prosedural, dan pengetahuan kondisional (Woolfolk, 2007, p. 267). Dengan demikian, metakognisi terdiri dari pengetahuan metakognitif (metacognitive knowledge) dan keterampilan metakognitif (metacognitive skills). Pengetahuan metakognitif yaitu pengetahuan tentang personal, tugas, dan strategi dalam belajar dan berpikir, serta berkait-an dengan pengetahuan deklaratif, pengetahuan prosedural, dan pengetahuan kondisional dalam dalam belajar dan berpikir. Keterampilan metakognitif, yaitu aksi metakognisi yang berkaitan dengan keterampilan perencanaan, keterampilan pemantauan, dan keterampilan evaluasi dalam belajar dan berpikir.

Metakognisi merupakan salah satu variabel yang penting dalam pendidikan dan pembelajaran. Berdasarkan pengkajian terhadap 179 hasil penelitian tentang prestasi belajar yang dilakukan Wang, Haertel, dan Walberg, ditemukan bahwa metakognisi berada pada peringkat pertama dari 200 faktor yang mempengaruhi hasil pendidikan (Shen \& Liu, 2011, p. 140). Pembelajaran yang mengaktifkan proses-proses metakognisi peserta didik (strategi metakognitif) adalah sebuah prediktor penting dari kemampuan memahami bacaan dalam buku teks sains (Haiduc \& Liliana, 2011, p. 550). Penggunaan metakognisi dalam bentuk tanya jawab dapat memperbaiki kegiatan belajar mengajar fisika di kelas dan meningkatkan minat siswa SMA terhadap fisika di sekolah (Campbell, 2007, p. 12). Penggunaan strategi metakognitif pada siswa mempunyai pengaruh yang signifikan pada proses membaca dan belajar fisika, serta kemampuan akademik fisika siswa (Akingbade \& Omotade, 2013, p. 473). Pembelajaran dengan siklus belajar metakognitif memberikan pengaruh yang signifikan terhadap prestasi akademik fisika siswa (Inomiesa, Achufusi, \& Mgbemena, 2013, p. 18).

Kemampuan metakognitif adalah kemampuan untuk menghubungkan pesan penting dengan pengetahuan sebelumnya, menarik kesimpulan, dan memantau atau menilai kinerja personal. Metakognisi merupakan proses kognitif tingkat tinggi dan merupakan tujuan akhir dari pembelajaran. Tujuan akhir dari pembelajaran adalah menyampaikan pengetahuan dan membangun kemampuan peserta didik untuk merencanakan, memantau, dan mengatur strategi belajar. Bantuan atau dukungan metakognitif dapat meningkatkan efektifitas belajar peserta didik (Shen \& Liu, 2011, p. 140).

Upaya memperkenalkan metakognisi kepada siswa agar peserta didik mampu menerapkan belajar bagaimana belajar cenderung terabaikan. Berdasarkan hasil observasi di lapangan pada beberapa sekolah, guru fisika masih ada yang belum memahami metakognisi. Guru fisika kurang membangun dan melatih metakognisi siswa. Guru-guru lebih mengutamakan kegiatan pembelajaran fisika yang bertujuan untuk menyampaikan materi pelajaran Fisika kepada siswa.

Belajar fisika adalah belajar mengidentifikasi, menginterpretasi, dan membuat inferensi terhadap suatu fenomena fisika agar siswa dapat memahami sistem fisika dan memecahkan masalah fisika. Dalam hal ini siswa memerlukan pengetahuan tentang apa yang diketahui dan tidak diketahui, keterampilan bagaimana memecahkan masalah, keterampilan membuat perencanaan pemecahan masalah, keterampilan 


\section{Jurnal Inovasi Pendidikan IPA, 4 (1), 2018 - 14}

Atep Koswara, M. Mundilarto

membuat tahap-tahap pemecahan masalah, memberi alasan mengapa memecahkan masalah dengan cara yang ditempuhnya, keterampilan memonitor proses belajar dan kemajuannya ke arah tujuan saat melaksanakan rencana, serta keterampilan mengevaluasi apa yang telah dilakukan (Gok, 2010, p. 116). Hal-hal tersebut merupakan bagian dari metakognisi.

Dalam pembelajaran fisika dibutuhkan penerapan stategi metakognitif. Melalui strategi metakognitif ini metakognisi siswa akan terlatih dan berkembang. Akan tetapi, terdapat kendala dalam penerapan stategi metakognitif. Banyaknya materi pelajaran fisika dan terbatasnya waktu pembelajaran di kelas merupakan kendala yang mempengaruhi penerapan strategi metakognitif dalam pembelajaran fisika. Penerapan strategi metakognitif dalam pembelajaran di kelas menjadi terbatas. Kegiatan melatih metakognisi siswa memiliki porsi yang sangat sedikit bahkan terabaikan.

Strategi pembelajaran metakognitif dapat dipadukan dengan bahan ajar. Pengajuan masalah dan aktivitas metakognitif dalam bahan ajar dapat dipadukan dengan pembelajaran yang berpusat pada siswa (Ghasempour, Bakar, \& Jahanshahloo, 2013, p. 57). Memadukan strategi pembelajaran metakognitif dengan pendekatan pertanyaan ke dalam isi materi pelajaran dilakukan untuk menghubungkan antara tugas kognitif dan keterampilan metakognitif yang relevan. Keterampilan metakognitif berupa aktivitas merencanakan, memonitor, dan mengevaluasi, dapat dipadukan dalam pembelajaran pemecahan masalah untuk memperbaiki kemampuan pemecahan masalah siswa (Gok, 2010, p. 117).

Untuk mengatasi keterbatasan penerapan strategi metakognitif dalam pelaksanaan pembelajaran fisika di kelas, perlu dikembangkan bahan ajar fisika tertulis (cetakan) yang terintegrasi metakognisi di dalamnya. Bahan ajar fisika tersebut harus dapat digunakan oleh siswa dan dapat membantu siswa dalam memperoleh alternatif bahan ajar di samping buku-buku teks yang terkadang sulit diperoleh, baik karena tidak tersedia atau harganya yang mahal. Dengan demikian, siswa dapat melakukan kegiatan belajar fisika sekaligus melatih dan mengaktifkan metakognisinya.

Berdasarkan hasil pengamatan di lapangan, bahan ajar fisika tertulis yang dibutuhkan siswa dalam pembelajaran adalah bahan ajar berbentuk handout. Bahan ajar adalah segala bentuk bahan berupa seperangkat materi yang disusun secara sistematis yang digunakan untuk membantu guru atau instruktur dalam melaksanakan kegiatan pembelajaran dan memungkinkan siswa untuk belajar (Departemen Pendidikan Nasional, 2008, p. 6). Handout dimaknai sebagai selembar atau beberapa lembar kertas yang diberikan guru kepada siswa secara terpisah-pisah (Prastowo, 2011, p. 78). Handout merupakan bentuk bahan ajar tertulis (cetak) paling sederhana yang dapat dikembangkan oleh guru dan digunakan oleh siswa. Guru dan siswa akan mendapatkan kemudahan dalam melaksanakan kegiatan pembelajaran dengan menggunakan handout. Sebuah handout akan menuntun guru dalam pembelajaran secara teratur dan jelas. Handout juga akan membantu siswa agar tidak terlalu banyak mencatat, karena banyak mencatat akan banyak menyita waktu.

Handout bahan ajar terintegrasi metakognisi merupakan alternatif bahan ajar sekaligus untuk melatih metakognisi siswa. Handout ini juga dapat digunakan di luar kelas dengan keleluasaan waktu belajar untuk mengatasi keterbatasan penerapan strategi metakognitif dalam mengaktifkan dan melatih metakognisi siswa di dalam kelas. Dengan menggunakan handout seperti ini, siswa akan dapat dengan mudah mempelajari materi pelajaran sekaligus mengaktifkan dan melatih metakognisinya untuk mengatasi kesulitan belajar fisika.

Handout bahan ajar terintegrasi metakognisi adalah handout yang berisi seperangkat materi pelajaran yang disusun secara sistematis yang menampilkan sosok utuh dari kompetensi yang akan dikuasai siswa yang di dalammya ditambahkan komponen metakognisi yang relevan dengan materi pelajaran tersebut. Komponen metakognisi yang ditambahkan ke dalam handout tersebut adalah pengetahuan dan keterampilan metakognitif. Pengetahuan metakognitif yang disajikan disesuaikan dengan pengetahuan faktual, konseptual, dan prosedural yang terdapat dalam materi pelajaran yang disajikan dalam handout tersebut. Keterampilan metakognitif dalam handout tersebut dilatihkan untuk membimbing siswa dalam mengatur kegiatan belajar dan berpikir untuk memecahkan masalah.

Berdasarkan hasil pengamatan di lapangan, handout bahan ajar terintegrasi metakognisi belum ada yang dikembangkan oleh guru-guru. Guru fisika yang diobservasi di lapangan belum pernah mengembangkan dan menggunakan handout bahan ajar terintegrasi metakognisi. Padahal, metakognisi dalam Kurikulum 2013 


\section{Jurnal Inovasi Pendidikan IPA, 4 (1), 2018 - 15}

Atep Koswara, M. Mundilarto

merupakan bagian dari kompetensi. Biasanya guru menggunakan bahan ajar cetak yang dikeluarkan oleh penerbit, baik berupa buku teks pelajaran Fisika maupun buku Lembar Kerja Siswa, yang tidak ada integrasi metakognisi di dalamnya.

Fluida dinamik merupakan salah satu materi pokok dalam mata pelajaran Fisika SMA/MA kelas XI MIPA berdasarkan Kurikulum 2013. Bahan ajar fluida dinamik cocok disusun dalam bentuk handout karena sesuai dengan materi fluida dinamik. Realita penerapan prinsip fluida dinamik dalam teknologi banyak ditemukan dalam kehidupan sehari-hari, seperti aerofoil, hidrofoil, pipa pitot, dan lain-lain, namun sulit untuk dihadirkan di dalam kelas, sehingga bisa dihadirkan dalam handout bahan ajar. Selain itu, pembelajaran materi fluida dinamik dengan menggunakan handout dapat dilakukan dengan menggunakan berbagai pendekatan, metode, maupun model pembelajaran.

Bahan ajar fluida dinamik cocok disusun dalam bentuk handout bahan ajar terintegrasi metakognisi karena sesuai dengan kompetensi dasar pada materi pokok tersebut, yaitu menerapkan prinsip fluida dinamik dalam teknologi. Dalam taksonomi hasil belajar Bloom yang telah mengalami revisi, kemampuan aplikasi (menerapkan) ini berada pada dimensi proses kognitif tingkat tiga. Proses kognitif aplikasi melibatkan penggunaan prosedur-prosedur tertentu untuk mengerjakan soal latihan atau menyelesaikan masalah (Anderson dan Krathwohl, 2010, p.43). Melatih kemampuan menerapkan (aplikatif) prinsip fluida dinamik dalam menyelesaikan soal-soal fisika akan banyak menyita waktu jika tidak disampaikan dalam bentuk bahan ajar tertulis.

Proses kognitif aplikasi terdiri dari dua proses kognitif, yaitu proses mengeksekusi dan mengimplementasikan Anderson \& Krathwohl (2010, p. 116). Proses mengeksekusi terjadi ketika tugas kognitifnya hanya latihan yang familiar. Dalam proses mengeksekusi, siswa secara rutin menerapkan pengetahuan prosedural yang harus digunakan yang umumnya telah diketahuinya. Tugas-tugas yang akrab (familiar) memberikan petunjuk yang cukup untuk memilih prosedur yang tepat digunakan. Proses mengimplementasikan terjadi ketika tugas kognitifnya merupakan masalah yang tidak akrab (familiar). Dalam proses mengimplementasikan, siswa harus menentukan pengetahuan apa yang akan mereka gunakan. Jika memerlukan pengetahuan prosedural dan tidak tersedia prosedur yang tepat, untuk menyelesaikan masalahnya siswa harus memodifikasi pengetahuan prosedur tersebut.

Kemampuan aplikatif merupakan proses kognitif yang terlibat dalam kegiatan penyelesaian soal atau pemecahan masalah fisika. Kemampuan pemecahan masalah fisika sangat erat hubungannya dengan metakognisi. Metakognisi merupakan sebuah faktor yang penting dalam pemecahan masalah fisika (Gok, 2010, p. 117). Terdapat hubungan yang signifikan antara metakognisi dan kemampuan pemecahan masalah fisika siswa (Anandaraj \& Ramesh, 2014, p. 191). Penggunaan strategi metakognitif mempunyai pengaruh yang positif terhadap kemampuan pemecahan masalah fisika siswa (Shareeja \& Gafoor, 2014, pp. 49-50). Memasukkan keterampilan metakognitif ke dalam pembelajaran akan mempertajam keterampilan pemecahan masalah siswa.

Handout bahan ajar fisika terintegrasi metakognisi pada materi pokok fluida dinamik berdasarkan pengamatan di lapangan, belum ada yang mengembangkan. Handout tersebut perlu dikembangkan sebagai alternatif bahan ajar materi pokok fluida dinamik yang sesuai tuntutan kurikulum dan mampu mengatasi masalah siswa dalam belajar fisika. Integrasi metakognisi pada bahan ajar fluida dinamik yang disajikan dalam bentuk handout akan membantu siswa agar menjadi trampil mengaplikasikan prinsipprinsip fisika dalam menjawab soal (memecahkan masalah) fluida dinamik.

Untuk memenuhi kebutuhan bahan ajar terintegrasi metakognisi sesuai tuntutan kurikulum dan kebutuhan siswa dalam belajar fisika, pada penelitian dan pengembangan ini dikembangkan handout bahan ajar fluida dinamik terintegrasi metakognisi. Tujuan penelitian ini adalah untuk (1) mengetahui kualitas handout bahan ajar fluida dinamik terintegrasi metakognisi, (2) mengetahui pengaruh penggunaan handout dalam meningkatkan kemampuan aplikatif prinsip fluida dinamik siswa SMA dan MA, dan (3) mengetahui kepraktisan penggunaan handout bahan ajar fluida dinamik terintegrasi metakognisi. Pengembangan ini diharapkan dapat memberikan manfaat, yaitu (1) dapat memperkaya pengetahuan tentang bahan ajar dan metakognisi dan (2) dapat bermanfaat bagi guru fisika dan siswa, yaitu tersedianya handout bahan ajar fisika terintegrasi metakognisi pada materi pokok fluida dinamik yang dapat digunakan untuk memudahkan siswa 
dalam belajar fisika sekaligus mengaktifkan dan melatih metakognisi.

\section{METODE}

Jenis penelitian yang digunakan adalah penelitian pengembangan. Penelitian pengembangan bertujuan untuk mengembangkan pengetahuan, teori pendidikan yang sudah ada, atau menghasilkan suatu produk di bidang pendidikan. Secara khusus penelitian pengembangan bertujuan untuk mengembangkan dan menguji produk yang dihasilkan (Diniaty \& Atun, 2015, p. 50).

Model pengembangan dalam penelitian ini berupa model prosedural yaitu model yang bersifat deskriptif, menggariskan langkahlangkah atau prosedur yang harus diikuti untuk menghasilkan produk. Langkah-langkah dari proses penelitian ini mengacu kepada sederetan uji coba yang hasil uji coba ini dianalisis guna dilakukan revisi terhadap produk yang sedang dikembangkan.

Model pengembangan yang digunakan dalam penelitian ini adalah model penelitian dan pengembangan (research and development) yang dikemukakan (Gall, Gall, \& Borg, 2007, p. 775). Model penelitian dan pengembangan tersebut terdiri dari 10 tahapan yang pada dasarnya terdiri dari dua tujuan utama, yaitu (1) mengembangkan produk, dan (2) menguji keefektifan produk dalam mencapai tujuan (validasi produk). 10 tahapan tersebut yaitu tahapan penelitian dan pengumpulan informasi (research and information collecting), perencanaan (planning), mengembangkan bentuk awal produk (develop preliminary form of product), uji lapangan permulaan (preliminary field testing), revisi produk utama (main product revision), uji lapangan utama (main field testing), revisi produk operasional (operational product revision), uji lapangan operasional (operational field testing), revisi produk akhir (final product revision), dan diseminasi dan distribusi (dissemination and distribution).

\section{Prosedur Pengembangan}

Langkah-langkah dari prosedur pengembangan handout bahan ajar fluida dinamik terintegrasi metakognisi adalah sebagai berikut: (1) melakukan analisis kurikulum, dalam hal ini adalah Kurikulum 2013; (2) melakukan analisis kebutuhan bahan ajar dan evaluasi bahan ajar yang tersedia menggunakan kompetensi inti (KI) dan kompetensi dasar (KD) sebagai dasarnya; (3) membuat keputusan tentang jenis materi yang akan dikembangkan berdasarkan hasil analisis dan evaluasi bahan ajar, apakah materi pokok atau pengayaan, dalam hal ini yang dikembangkan adalah materi pokok bukan materi pengayaan; (4) menentukan judul bahan ajar (dalam hal ini berbentuk handout), sesuaikan dengan KD dan materi pokok yang akan dicapai; (5) membuat keputusan tentang bentuk isi handout, apakah overview atau ringkasan, dalam hal ini bentuk isi handout berupa overview bukan ringkasan materi; (6) membuat keputusan tentang cara penyajian, apakah narasi, tabel, gambar, diagram, atau kombinasi dari semuanya, dalam hal ini cara penyajian yang digunakan pada handout adalah dalam bentuk kombinasi dari narasi dan gambar (skema); (7) mengumpulkan referensi (sumber belajar) sebagai bahan penulisan handout yang terkini dan relevan dengan materi pokoknya yaitu fluida dinamik; (8) mengumpulkan referensi tentang metakognisi sebagai bahan untuk menentukan komponen metakognisi dan strategi metakognitif yang bisa ditambahkan ke dalam handout bahan ajar fluida dinamik yang terkini dan relevan dengan KD dan materi pokok fluida dinamik; (9) melakukan penulisan naskah handout dengan menguraikan materi pokok fluida dinamik dalam bentuk narasi disertai gambar (skema), contoh soal, serta soal-soal latihan yang disesuaikan dengan tingkat berpikir siswa SMA/MA; (10) menambahkan ke dalam handout pengetahuan metakognitif (berupa pengetahuan strategi, diri, tugas kognitif, deklaratif spesifik ranah, prosedural spesifik ranah, dan kondisional spesifik ranah) dan keterampilan metakognitif (berupa keterampilan merencanakan, mengontrol, dan mengevaluasi) yang memungkinkan sesuai dengan $\mathrm{KD}$ dan materi pokok fluida dinamik; (11) melakukan evaluasi hasil penulisan dengan cara dibaca ulang, dinilai oleh ahli pendidikan fisika dan guru fisika SMA/MA, untuk keperluan perbaikan (revisi) terhadap handout, dan (12) melakukan perbaikan (revisi) handout sesuai dengan komentar dan saran yang dikemukakan oleh ahli pendidikan fisika dan guru fisika SMA/MA.

\section{Desain Uji Coba}

Untuk mengetahui pengaruh penggunaan handout yang dikembangkan terhadap peningkatan kemampuan aplikatif siswa SMA/MA dilakukan uji coba penggunaan pada kegiatan uji lapangan utama. Desain yang digunakan pada uji lapangan utama adalah desain penelitian eksperimen semu faktorial $2 \times 2$. Desain pene- 
litian eksperimen semu faktorial adalah desain penelitian eksperimen faktorial yang tidak menggunakan prosedur randomisasi dalam penentuan dan penempatan subjek penelitian ke dalam kelompok-kelompok perlakuannya (Gall et al., 2007, p. 404). Skema desain penelitian eksperimen semu faktorial $2 \times 2$ yang digunakan dalam uji lapangan utama penelitian ini ditunjukkan pada Gambar 1dan Tabel 1. Faktor pertama dalam penelitian ini adalah bentuk bahan ajar. Bentuk bahan ajar tersebut adalah handout bahan ajar terintegrasi metakognisi dan bahan ajar lain (Buku Fokus Fisika) yang digunakan di sekolah lokasi penelitian. Faktor kedua dalam penelitian ini adalah bentuk satuan pendidikan menengah umum. Bentuk satuan pendidikan menengah umum tersebut adalah SMA dan MA. Variabel terikat dalam penelitian ini adalah peningkatan kemampuan aplikatif siswa SMA dan MA dalam materi pokok fluida dinamik.

\begin{tabular}{|c|c|c|c|}
\hline & \multicolumn{2}{|c|}{$\begin{array}{c}\text { Bentuk Bahan Ajar } \\
\text { yang Digunakan }\end{array}$} \\
\hline & & $\begin{array}{c}\text { Handout } \\
\text { Terintegrasi } \\
\text { Metakognisi }\end{array}$ & $\begin{array}{l}\text { Buku } \\
\text { Fokus } \\
\text { Fisika }\end{array}$ \\
\hline \multirow{2}{*}{ 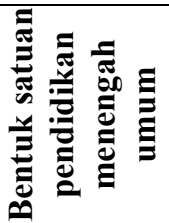 } & SMA & $\mathrm{S}+\mathrm{H}$ & $\mathrm{S}+\mathrm{B}$ \\
\hline & MA & $\mathrm{M}+\mathrm{H}$ & $\mathrm{M}+\mathrm{B}$ \\
\hline
\end{tabular}

Gambar 1. Skema Desain Penelitian pada Tahapan Uji Lapangan Utama

Tabel 1. Rancangan Uji Coba pada Kegiatan Uji Lapangan Utama

\begin{tabular}{cccc}
\hline Sampel & Awal & Perlakuan & Akhir \\
\hline $\mathrm{E}$ & $\mathrm{O}_{1}$ & $\mathrm{X}_{1}$ & $\mathrm{O}_{2}$ \\
$\mathrm{~K}$ & $\mathrm{O}_{3}$ & $\mathrm{X}_{2}$ & $\mathrm{O}_{4}$ \\
\hline \multicolumn{2}{l}{ Keterangan : } \\
$\mathrm{E}=$ Kelas Eksperimen (Kelas yang menggunakan \\
\multicolumn{3}{r}{ Handout Terintegrasi Metakognisi) } \\
$\mathrm{K}=$ Kelas Kontrol (Kelas yang menggunakan Buku \\
Fokus Fisika yang sudah ada) \\
$\mathrm{O}_{1}=$ Tes Awal untuk kelas eksperimen \\
$\mathrm{O}_{2}=$ Tes Akhir untuk kelas eksperimen \\
$\mathrm{O}_{3}=$ Tes Awal untuk kelas kontrol \\
$\mathrm{O}_{4}=$ Tes Akhir untuk kelas kontrol \\
$\mathrm{X}_{1}=$ Perlakuan dengan menggunakan Handout \\
Terintegrasi Metakognisi \\
$\mathrm{X}_{2}=$ Perlakuan dengan menggunakan Buku Fokus \\
Fisika yang sudah ada
\end{tabular}

\section{Waktu dan Tempat Penelitian}

Penelitian ini dilaksanakan pada semester genap tahun ajaran 2014/2015 dari bulan Pebruari sampai dengan Mei tahun 2015. Uji lapangan produk dilaksanakan di dua sekolah uji coba, yaitu di SMAN 8 Yogyakarta dan MAN Laboratorium UIN Yogyakarta.

\section{Subjek Uji Coba}

Subjek uji coba dalam penelitian ini adalah siswa kelas XI MIPA pada SMAN 8 Yogyakarta dan MAN Laboratorium UIN Yogyakarta. Uji lapangan permulaan menggunakan responden satu kelas siswa pada SMAN 8 Yogyakarta. Uji lapangan utama menggunakan subjek dua kelas siswa pada SMAN 8 Yogyakarta dan dua kelas siswa pada MAN Laboratorium UIN Yogyakarta. Uji lapangan operasional menggunakan responden dua kelas siswa pada SMAN 8 Yogyakarta.

\section{Teknik dan Intrumen Pengumpulan Data}

Teknik pengumpulan data pada proses penilaian handout oleh ahli pendidikan fisika dan guru fisika SMA/MA menggunakan teknik nontes. Instrumen yang digunakan pada kegiatan ini adalah Lembar Penilaian Handout Bahan Ajar Fluida Dinamik Terintegrasi Metakognisi oleh Ahli Pendidikan Fisika dan Lembar Penilaian Handout Bahan Ajar Fluida Dinamik Terintegrasi Metakognisi oleh Guru Fisika SMA/MA yang berupa angket berbentuk skala. Berdasarkan hasil validasi rasional oleh ahli, kedua instrumen tersebut layak digunakan.

Teknik pengumpulan data pada tahapan uji lapangan permulaan menggunakan teknik nontes. Instrumen yang digunakan pada kegiatan ini adalah Lembar Tanggapan Siswa Terhadap Handout Bahan Ajar Fluida Dinamik Terintegrasi Metakognisi yang berupa angket berbentuk skala. Berdasarkan hasil validasi rasional oleh ahli, instrumen tersebut layak digunakan.

Teknik pengumpulan data pada tahapan uji lapangan utama menggunakan teknik tes. Instrumen yang digunakan pada kegiatan ini adalah Tes Awal Kemampuan Menerapkan Prinsip Fluida Dinamik (Tes Awal) dan Tes Akhir Kemampuan Menerapkan Prinsip Fluida Dinamik (Tes Akhir) berbentuk soal-soal uraian. Berdasarkan hasil validasi rasional oleh ahli, isi dan konstruks kedua instrumen tersebut valid. Hasil uji empiris Tes Awal dan Tes akhir disajikan dalam Tabel 2. 
Jurnal Inovasi Pendidikan IPA, 4 (1), 2018 - 18

Atep Koswara, M. Mundilarto

Tabel 2. Hasil Uji Empiris Tes Awal dan Tes Akhir yang Digunakan

\begin{tabular}{lcc}
\hline \multicolumn{1}{c}{ Aspek } & Tes Awal & Tes Akhir \\
\hline Koefisien reliabilitas & 0.77 & 0.82 \\
Reliabilitas & reliabel & reliabel \\
Rata-rata koefisian korelasi butir-total & 0.71 & 0.55 \\
Validitas & valid & valid \\
Rata-rata tingkat kesukaran & 0.56 & 0.70 \\
Kategori tingkat kesukaran & sedang & sedang \\
Rata-rata daya pembeda & 0.39 & 0.27 \\
Kategori daya pembeda & baik & baik \\
Jumlah butir & 6 & 6 \\
\hline
\end{tabular}

Teknik pengumpulan data pada tahapan uji lapangan operasional menggunakan teknik nontes. Instrumen yang digunakan pada kegiatan ini adalah Lembar Tanggapan Guru Fisika SMA/MA terhadap Penggunaan Handout Bahan Ajar Fluida Dinamik Terintegrasi Metakognisi dan Lembar Tanggapan Siswa SMA/MA terhadap Penggunaan Handout Bahan Ajar Fluida Dinamik Terintegrasi Metakognisi yang berupa angket berbentuk skala. Berdasarkan hasil validasi rasional oleh ahli, kedua instrumen tersebut layak digunakan.

\section{Teknik Analisis Data}

Teknik analisis data yang digunakan pada data hasil penilaian ahli pendidikan fisika dan guru fisika SMA/MA, hasil uji lapangan permulaan, dan hasil uji lapangan operasional menggunakan statistik deskriptif dengan menghitung rata-rata skor angket lembar tanggapan responden menggunakan Persamaan (1) berikut ini.

$\bar{X}=\frac{\sum_{i}^{n} X_{i}}{n}$,

dengan

$\bar{X}=$ rata-rata skor,

$X_{i}=$ skor yang diberikan responden ke-i, dan

$n$ = banyaknya responden.

Rata-rata skor tersebut dikonversi menjadi data kualitatif menggunakan aturan konversi seperti yang tercantum dalam Tabel 3 (Direktorat Pembinaan SMA, 2010, p. 60).

Untuk menentukan peningkatan kemampuan aplikatif (kemampuan menerapkan) prinsip fluida dinamik siswa SMA dan MA digunakan teknik analisis gain score aktual menurut Hake (1998, p. 65) dengan menggunakan Persamaan (2) berikut ini.

$\langle G\rangle=\left\langle S_{f}\right\rangle-\left\langle S_{i}\right\rangle$,

dimana

$\langle G\rangle=$ gain score (peningkatan skor) aktual,

$\left\langle S_{f}\right\rangle=$ skor tes akhir, dan

$\left\langle S_{i}\right\rangle=$ skor tes awal.
Tabel 3. Konversi Data Kuantitatif Menjadi Data Kualitatif Skala Empat

\begin{tabular}{ccc}
\hline No. & Rentang Skor & Kriteria \\
\hline 1. & $\mathrm{Mi}+1,5 \mathrm{SDi} \leq \mathrm{X} \leq \mathrm{Mi}+3,0 \mathrm{SDi}$ & Amat baik \\
2. & $\mathrm{Mi}+0 \mathrm{SDi} \leq \mathrm{X}<\mathrm{Mi}+1,5 \mathrm{SDi}$ & Baik \\
3. & $\mathrm{Mi}-1,5 \mathrm{SDi} \leq \mathrm{X}<\mathrm{Mi}+0 \mathrm{SDi}$ & Cukup \\
4. & $\mathrm{Mi}-3,0 \mathrm{SDi} \leq \mathrm{X}<\mathrm{Mi}-1,5 \mathrm{SDi}$ & Kurang \\
\hline
\end{tabular}

Keterangan:

$\mathrm{X}=$ skor empiris (rata-rata skor responden)

$\mathrm{Mi}=$ rata-rata skor ideal

$=1 / 2($ skor tertinggi ideal + skor terendah ideal $)$

$\mathrm{Sdi}=$ standar deviasi skor ideal

$=1 / 6$ (skor tertinggi ideal - skor terendah ideal)

Skor tertinggi ideal $=\Sigma$ butir kriteria $\mathrm{x}$ skor tertinggi

Skor terendah ideal $=\Sigma$ butir kriteria $\mathrm{x}$ skor terendah

Untuk menentukan kategori peningkatan kemampuan aplikatif prinsip fluida dinamik siswa SMA/MA (peningkatan kemampuan menerapkan prinsip fluida dinamik) digunakan teknik analisis gain score ternormalisasi menurut Hake (1998, p.65) dengan menggunakan Persamaan (3) berikut ini.

$\langle\mathrm{g}\rangle=\frac{\left(S_{f}\right)-\left(s_{i}\right)}{100-\left(s_{i}\right)}$,

(3) di mana

$\langle\mathrm{g}\rangle=$ gain score (peningkatan skor) ternormalisasi,

$\left\langle S_{f}\right\rangle=$ skor tes akhir, dan

$\left\langle S_{i}\right\rangle=$ skor tes awal.

Gain score ternormalisasi tersebut dikonversi menjadi data kualitatif menggunakan aturan konversi menurut Hake (1998, p. 65) seperti yang tercantum dalam Tabel 4.

Tabel 4. Konversi Gain Score Ternormalisasi Menjadi Data Kualitatif Skala Tiga

\begin{tabular}{ccc}
\hline No. & $\begin{array}{c}\text { Rentang Gain Score } \\
\text { Ternormalisasi }(\langle\mathrm{g}\rangle)\end{array}$ & Kriteria \\
\hline 1. & $\langle\mathrm{~g}\rangle \geq 0,7$ & tinggi \\
2. & $0,3 \leq\langle\mathrm{g}\rangle<0,7$ & sedang \\
3. & $\langle\mathrm{~g}\rangle<0,3$ & rendah \\
\hline
\end{tabular}

Teknik analisis data hasil uji lapangan utama menggunakan analisis varian (anava) dua jalur untuk mengetahui pengaruh faktor terhadap 
variabel bebas. Teknik analisis tersebut dilakukan menggunakan program komputer SPSS versi 16. Sebelum uji anava dilakukan, terlebih dahulu dilakukan uji prasyarat, yaitu uji normalitas dan homogenitas gain score dari seluruh kelas subjek uji coba.

\section{HASIL DAN PEMBAHASAN}

\section{Hasil Pengembangan}

Hasil dari tahapan pengembangan bentuk awal produk adalah draft awal handout bahan ajar fluida dinamik terintegrasi metakognisi. Draft handout tersebut merupakan bahan ajar materi pokok fluida dinamik yang ditambahkan padanya komponen metakognisi. Komponen metakognisi disajikan dalam rubrik-rubrik tersendiri yang tidak menyatu dalam naskah uraian materi pokok.

Untuk mendapatkan handout hasil pengembangan yang siap diuji lapangan, dilakukan proses penilaian dan revisi terhadap draft awal handout. Hasil penilaian ahli pendidikan fisika terhadap draft handout bahan ajar fluida dinamik terintegrasi metakognisi disajikan dalam Tabel 5. Hasil penilaian guru fisika SMA/MA terhadap draft handout bahan ajar fluida dinamik terintegrasi metakognisi disajikan dalam Tabel 6.

Berdasarkan hasil penilaian ahli pendidikan fisika dan guru fisika SMA/MA, draft handout bahan ajar fluida dinamik terintegrasi metakognisi yang dikembangkan memiliki kualitas yang sangat baik. Kegiatan revisi pada tahap ini yaitu perbaikan tata kalimat dan tata bahasa, penambahan gambar pada penyelesaian contoh soal, penyesuaian soal latihan terhadap contoh soal, perbaikan kunci jawaban soal latihan, dan penekanan penerapan aspek metakognisi pada penyelesaian contoh soal.

Setelah draft handout tersebut diperbaiki sesuai dengan komentar dan saran dari penilai, diperoleh hasil akhir dari tahap pengembangan bentuk awal produk dalam penelitian dan pengembangan ini yaitu sebuah handout bahan ajar fluida dinamik terintegrasi metakognisi yang telah siap diuji lapangan. Handout tersebut berisi uraian materi pelajaran, contoh soal, seperangkat latihan, tugas, pengetahuan metakognitif, dan keterampilan metakognitif. Secara garis besar, struktur handout bahan ajar terintegrasi metakognisi terdiri dari: (1) Identitas handout yang disertai dengan Kompetensi Dasar, indikator, tujuan pembelajaran, pengetahuan prasyarat, dan pendahuluan tentang penggunaan keterampilan metakognitif (merencanakan, mengontrol, dan mengevaluasi) dalam kegiatan belajar siswa dengan menggunakan handout; (2) Uraian materi pelajaran berupa pengetahuan faktual, konseptual, dan prosedural sesuai dengan kompetensi dasar yang ditambahkan pengetahuan metakognitif (pengetahuan deklaratif, pengetahuan strategi, pengetahuan diri, dan pengetahuan tugas kognitif) yang relevan dengan materi pelajaran tersebut; (3) Contoh soal penerapan pengetahuan konseptual dan prosedural dari materi pelajaran yang disajikan disertai dengan penggunaan keterampilan metakognitif (merencanakan, mengontrol, dan mengevaluasi), pengetahuan prosedural, dan pengetahuan kondisional dalam penyelesaian soal tersebut; (4) Soal latihan sesuai kompetensi dasar disertai dengan pengetahuan metakognitif (pengetahuan strategi, pengetahuan diri, dan pengetahuan tugas kognitif) dan petunjuk yang mengarahkan siswa untuk menggunakan metakognisi dalam belajar dan berpikirnya; (5) Tugas yang disertai dengan petunjuk yang mengarahkan siswa untuk menggunakan metakognisi dalam belajar dan berpikirnya; dan (6) Daftar referensi yang terkait dengan materi pelajaran yang disajikan.

Tabel 5. Hasil Penilaian Ahli Pendidikan Fisika terhadap Draft Awal Handout

\begin{tabular}{lcccc}
\hline \multicolumn{1}{c}{ Komponen } & Skor Total & Skor rata-rata & Persentase Keidealan & Kesimpulan Kualitas \\
\hline kelayakan isi/materi & 70 & 35 & $87,50 \%$ & sangat baik \\
penyajian materi & 80 & 40 & $83,33 \%$ & sangat baik \\
kebahasaan & 90 & 45 & $86,54 \%$ & sangat baik \\
kegrafikaan & 238 & 119 & $87,50 \%$ & sangat baik \\
metakognisi & 62 & 31 & $86,11 \%$ & sangat baik \\
keseluruhan & $\mathbf{5 4 0}$ & $\mathbf{2 7 0}$ & $\mathbf{8 6 , 5 4 \%}$ & sangat baik \\
\hline
\end{tabular}


Jurnal Inovasi Pendidikan IPA, 4 (1), 2018 - 20

Atep Koswara, M. Mundilarto

Tabel 6. Hasil Penilaian Guru Fisika SMA/MA terhadap Draft Awal Handout

\begin{tabular}{|c|c|c|c|c|}
\hline Komponen & Skor total & Skor rata-rata & Persentase keidealan & Kesimpulan kualitas \\
\hline kelayakan isi/materi & 75 & 37,5 & $93,75 \%$ & sangat baik \\
\hline penyajian materi & 91 & 45,5 & $94,79 \%$ & sangat baik \\
\hline kebahasaan & 93 & 46,5 & $89,42 \%$ & sangat baik \\
\hline kegrafikaan & 251 & 125,5 & $92,28 \%$ & sangat baik \\
\hline metakognisi & 66 & 33 & $91,67 \%$ & sangat baik \\
\hline keseluruhan & 576 & 288 & $92,31 \%$ & sangat baik \\
\hline
\end{tabular}

Tabel 7. Hasil Analisis Data Tanggapan Siswa SMA Peserta Uji Lapangan Permulaan terhadap Handout Bahan Ajar Fluida Dinamik Terintegrasi Metakognisi.

\begin{tabular}{lcccc}
\hline \multicolumn{1}{c}{ Komponen } & Skor total & Skor rata-rata & Persentase keidealan & Kesimpulan kualitas \\
\hline kelayakan isi/materi & 931 & 33,25 & $83,13 \%$ & sangat baik \\
penyajian materi & 1023 & 36,54 & $76,12 \%$ & baik \\
kebahasaan & 504 & 18,00 & $75,00 \%$ & baik \\
kegrafikaan & 1980 & 70,71 & $80,36 \%$ & baik \\
metakognisi & 876 & 31,29 & $78,21 \%$ & baik \\
keseluruhan & $\mathbf{5 3 1 4}$ & $\mathbf{1 8 9 , 7 8}$ & $\mathbf{7 9 , 0 8 \%}$ & baik \\
\hline
\end{tabular}

\section{Hasil Uji Coba Produk}

Uji lapangan yang dilakukan terhadap handout bahan ajar tersebut adalah uji lapangan permulaan, uji lapangan utama, dan uji lapangan operasional. Masing-masing uji lapangan tersebut memiliki tujuan yang berbeda. Tujuan uji lapangan permulaan adalah untuk mengetahui kualitas handout bahan ajar yang dikembangkan menurut tanggapan calon pengguna. Tujuan uji lapangan utama adalah untuk menentukan apakah handout bahan ajar yang dikembangkan dapat mencapai tujuan penggunaannya, yaitu untuk meningkatkan kemampuan aplikatif prinsip fluida dinamik siswa SMA dan MA. Tujuan uji lapangan operasional adalah untuk mengetahui apakah handout bahan ajar yang dikembangkan benar-benar telah siap digunakan di lapangan tanpa kehadiran pengembang.

Subjek uji lapangan permulaan adalah satu kelas siswa kelas XI MIA pada SMAN 8 Yogyakarta yang berjumlah 28 orang. Hasil uji lapangan permulaan disajikan dalam Tabel 7.

Berdasarkan data pada Tabel 7 dapat dikemukakan bahwa menurut tanggapan siswa SMA, handout bahan ajar yang dikembangkan secara keseluruhan kualitasnya baik. Hal tersebut diakibatkan oleh kualitas komponenkomponennya yang baik juga. Walaupun ada satu komponen yang kualitasnya sangat baik yaitu komponen kelayakan isi/materi, tetapi komponen yang lainnya berkualitas baik.
Pada kegiatan uji lapangan permulaan diperoleh juga beberapa komentar dan saran dari siswa SMA peserta uji lapangan permulaan untuk perbaikan handout bahan ajar fluida dinamik terintegrasi metakognisi. Handout tersebut kemudian diperbaiki sesuai dengan komentar dan saran dari siswa SMA sebelum dilakukan uji lapangan utama. Kegiatan revisi pada tahap ini yaitu perbaikan tata kalimat dan tata bahasa, meringkas uraian materi, dan memperjelas tampilan gambar.

Karena menurut tanggapan siswa SMA peserta uji lapangan permulaan, handout bahan ajar fluida dinamik terintegrasi metakognisi yang dikembangkan berkualitas baik, jadi handout tersebut telah siap digunakan pada uji lapangan utama. Hasil akhir dari uji lapangan permulaan dalam penelitian dan pengembangan ini adalah sebuah handout bahan ajar fluida dinamik terintegrasi metakognisi yang telah siap digunakan pada uji lapangan utama.

Pada uji lapangan utama dilakukan eksperimen penggunaan handout bahan ajar fluida dinamik terintegrasi metakognisi dalam kegiatan pembelajaran di dua sekolah, yaitu di SMAN 8 Yogyakarta dan MAN Laboratorium UIN Yogyakarta. Eksperimen tersebut dilakukan terhadap empat kelas siswa di dua sekolah yaitu dua kelas di SMAN 8 Yogyakarta dan dua kelas di MAN Laboratorium UIN Yogyakarta dengan peneliti bertindak sebagai guru. 
Jurnal Inovasi Pendidikan IPA, 4 (1), 2018 - 21

Atep Koswara, M. Mundilarto

Tabel 8. Rata-rata Skor Tes Awal.

\begin{tabular}{|c|c|c|}
\hline Sekolah & Kelas & Rata-rata Skor Tes Awal \\
\hline \multirow[t]{2}{*}{ SMAN 8 Yogyakarta } & XI MIA 2 & 15,35 \\
\hline & XI MIA 5 & 14,31 \\
\hline \multirow[t]{2}{*}{ MAN Lab. UIN Yogyakarta } & XI IPA 1 & 14,83 \\
\hline & XI IPA 2 & 11,25 \\
\hline
\end{tabular}

Keterangan: Skor maksimum Tes Awal adalah 63.

Tabel 9. Rata-rata Skor Tes Akhir.

\begin{tabular}{cccc}
\hline \multicolumn{1}{c}{ Sekolah } & Kelas & Status kelas & Rata-rata Skor Tes Akhir \\
\hline SMAN 8 Yogyakarta & XI MIA 2 & Kontrol & 37,81 \\
& XI MIA 5 & Eksperimen & 56,59 \\
MAN Lab. UIN Yogyakarta & XI IPA 1 & Eksperimen & 33,83 \\
& XI IPA 2 & Kontrol & 21,65 \\
\hline
\end{tabular}

Keterangan: Skor maksimum Tes Akhir adalah 63.

Tabel 10. Nilai sig. Hasil Uji Beda Rata-rata Skor Tes Awal.

\begin{tabular}{cccc}
\hline \multicolumn{1}{c}{ Sekolah } & Kelas & Teknik Analisis & Nilai sig. \\
\hline SMAN 8 Yogyakarta & XI MIA 2 & uji Mann Whitney & 0,505 \\
MAN Lab. UIN Yogyakarta & $\begin{array}{l}\text { XI MIA 5 } \\
\text { XI IPA 1 }\end{array}$ & uji t & 0,023 \\
\hline
\end{tabular}

Jika penggunaan handout bahan ajar fluida dinamik terintegrasi metakognisi pada uji lapangan utama menghasilkan peningkatan kemampuan aplikatif prinsip fluida dinamik siswa SMA dan MA yang signifikan, maka handout tersebut telah siap digunakan dalam uji lapangan operasional. Untuk mengetahui peningkatan kemampuan aplikatif prinsip fluida dinamik siswa SMA/MA dilakukan pengukuran menggunakan tes awal dan tes akhir kemampu-an menerapkan prinsip fluida dinamik. Rata-rata skor tes awal dan tes akhir masing-masing kelas pada kedua sekolah disajikan dalam Tabel 8 dan Tabel 9.

Untuk mengetahui karakteristik kemampuan awal dari subjek uji coba, dilakukan uji beda rata-rata terhadap data hasil tes awal antar kelas di masing-masing sekolah. Kemampuan awal subjek uji coba dapat diketahui dari hasil tes awal. Hasil uji beda rata-rata skor tes awal antar kelas pada kedua sekolah disajikan pada Tabel 10.

Hasil analisis pada Tabel 10 menunjukkan bahwa tidak ada perbedaan yang signifikan pada rata-rata skor tes awal antara kedua kelas di SMAN 8 Yogyakarta dan ada perbedaan yang signifikan pada rata-rata skor tes awal antara kedua kelas di MAN Laboratorium UIN Yogyakarta. Hasil analisis skor tes awal pada kedua sekolah dijadikan pertimbangan dalam menentukan kelas eksperimen dan kontrol. Pada SMAN 8 Yogyakarta, kelas XI MIA 5 digunakan sebagai kelas eksperimen dan kelas XI MIA
2 sebagai kelas kontrol. Pada MAN Laboratorium UIN Yogyakarta, yang digunakan sebagai kelas eksperimen adalah kelas XI IPA 1 dan kelas XI IPA 2 sebagai kelas kontrol.

Untuk mengetahui apakah terdapat perbedaan yang signifikan pada kemampuan akhir dari subjek uji coba, dilakukan uji beda rata-rata terhadap data hasil tes akhir antar kelas di masing-masing sekolah. Hasil uji beda rata-rata skor tes akhir antar kelas pada kedua sekolah disajikan pada Tabel 11.

Tabel 11. Nilai sig. Hasil Uji Beda (Uji Mann Whitney) Rata-rata Skor Tes Akhir.

\begin{tabular}{lc}
\hline \multicolumn{1}{c}{ Sekolah } & Nilai sig. \\
\hline SMAN 8 Yogyakarta & 0.000 \\
\hline MAN Lab. UIN Yogyakarta & 0,001 \\
\hline
\end{tabular}

Hasil analisis tersebut menunjukkan bahwa ada perbedaan yang signifikan pada rata-rata skor tes akhir antara kedua kelas di SMAN 8 Yogyakarta dan di MAN Laboratorium UIN Yogyakarta. Rata-rata skor tes akhir kelas eksperimen lebih besar daripada rata-rata skor tes akhir kelas kontrol di kedua sekolah tempat uji coba.

Untuk menentukan apakah terdapat perbedaan yang signifikan antara skor tes awal dan tes akhir, dilakukan uji beda rata-rata (Uji Peringkat Bertanda Wilcoxon) terhadap data hasil tes awal dan tes akhir pada semua kelas di masing-masing sekolah. Hasil uji beda rata-rata skor tes awal dan tes akhir masing-masing kelas pada kedua sekolah disajikan pada Tabel 12 . 
Hasil analisis pada Tabel 12 menunjukkan bahwa ada perbedaan yang signifikan pada ratarata skor tes awal dan tes akhir pada masingmasing kelas di SMAN 8 Yogyakarta dan di MAN Laboratorium UIN Yogyakarta. Rata-rata skor tes akhir lebih besar daripada rata-rata skor tes awal pada semua kelas di kedua sekolah tempat uji coba. Hal tersebut menunjukkan adanya peningkatan yang signifikan pada kemampuan menerapkan prinsip fluida dinamik siswa SMA/MA peserta uji lapangan utama di kedua sekolah.

Tabel 12. Nilai sig. Hasil Uji Beda (Uji Peringkat Bertanda Wilcoxon) Rata-rata Skor Tes Awal dan Tes Akhir.

\begin{tabular}{lcc}
\hline \multicolumn{1}{c}{ Sekolah } & Kelas & Nilai sig. \\
\hline SMAN 8 Yogyakarta & Kontrol & 0,000 \\
& Eksperimen & 0,000 \\
MAN Lab. UIN & Eksperimen & 0,000 \\
Yogyakarta & Kontrol & 0,000 \\
\hline
\end{tabular}

Berdasarkan hasil tes awal dan tes akhir, diperoleh peningkatan (gain) skor tes kemampuan menerapkan prinsip fluida dinamik siswa SMA/MA peserta uji lapangan utama pada kedua sekolah. Hasil analisis gain skor tes pada uji lapangan utama disajikan dalam Tabel 13 dan Tabel 14.

Tabel 13. Hasil Analisis Gain Score $(\langle G\rangle)$.

\begin{tabular}{lcc}
\hline \multicolumn{1}{c}{ Sekolah } & Kelas & $\langle G\rangle$ \\
\hline \multirow{2}{*}{ SMAN 8 Yogyakarta } & Kontrol & 22,46 \\
MAN LAB. UIN & Eksperimen & 42,28 \\
Yogyakarta & Eksperimen & 19,00 \\
\hline
\end{tabular}

Tabel 14. Hasil Analisis Gain Score Ternormalisasi $(\langle g\rangle)$

\begin{tabular}{lccc}
\hline \multicolumn{1}{c}{ Sekolah } & Kelas & $\langle g\rangle$ & Kategori \\
\hline SMAN 8 Yogyakarta & Kontrol & 0,46 & sedang \\
MAN Lab. UIN & Eksperimen & 0,86 & tinggi \\
Yogyakarta & Eksperimen & 0,40 & sedang \\
\hline
\end{tabular}

Untuk mengetahui apakah terdapat perbedaan yang signifikan pada peningkatan kemampuan menerapkan prinsip fluida dinamik siswa SMA/MA peserta uji lapangan utama pada kedua sekolah, dilakukan uji beda rata-rata terhadap data gain score antar kelas di masingmasing sekolah. Hasil uji beda rata-rata gain score antar kelas pada kedua sekolah disajikan pada Tabel 15.

Hasil analisis pada Tabel 15 menunjukkan bahwa ada perbedaan yang signifikan pada ratarata gain score antara kedua kelas di SMAN 8
Yogyakarta dan di MAN Laboratorium UIN Yogyakarta. Rata-rata gain score kelas eksperimen lebih besar daripada rata-rata skor tes akhir kelas kontrol di kedua sekolah tempat uji coba.

Tabel 15. Nilai sig. Hasil Uji Beda (Uji t) Ratarata Gain Score antar Kelas Pada Kedua

Sekolah.

\begin{tabular}{lc}
\hline \multicolumn{1}{c}{ Sekolah } & Nilai sig. \\
\hline SMAN 8 Yogyakarta & 0.000 \\
\hline MAN Lab. UIN Yogyakarta & 0,002 \\
\hline
\end{tabular}

Karena terdapat perbedaan yang signifikan antara rata-rata skor tes awal antara kelas XI IPA 1 dan XI IPA 2 pada MAN Laboratorium UIN Yogyakarta, dilakukan uji anakova terhadap data gain score, skor tes awal, dan bahan ajar. Hasil uji anakova tersebut disajikan pada Tabel 16.

Tabel 16. Nilai sig. Hasil Uji Anakova terhadap

Data Gain Score, Skor Tes Awal, dan Bahan Ajar Pada MAN Laboratorium UIN Yogyakarta.

\begin{tabular}{lc}
\hline \multicolumn{1}{c}{ Sumber Keragaman } & Nilai sig. \\
\hline Tes Awal & 0,692 \\
Bahan Ajar & 0,006 \\
\hline
\end{tabular}

Hasil analisis tersebut menunjukkan bahwa perbedaan skor tes awal tidak berpengaruh terhadap perbedaan gain score pada kelas XI IPA 1 dan XI IPA 2. Perbedaan gain score pada kelas eksperimen dan kelas kontrol di MAN Laboratorium UIN Yogyakarta hanya dipengaruhi oleh perbedaan penggunaan bentuk bahan ajar (perlakuan) dan tidak dipengaruhi perbedaan skor tes awal.

Untuk mengetahui faktor yang berpengaruh terhadap adanya perbedaan antara rata-rata gain score pada kelas eksperimen dan rata-rata gain score pada kelas kontrol dilakukan analisis varian (anava) dua jalur terhadap data dari kedua sekolah. Sebelum dilakukan uji anava dua jalur, dilakukan uji prasyarat. Hasil uji prasyarat menunjukkan bahwa data memenuhi persyaratan uji anava. Analisis varian dilakukan terhadap data gain score, jenis bahan ajar, dan jenis sekolah. Hasil uji Anava dapat dilihat pada Tabel 17 .

Tabel 17. Nilai sig. Hasil Uji Anava Terhadap Data Gain Score, Jenis Bahan Ajar, dan Jenis Sekolah.

\begin{tabular}{lc}
\hline \multicolumn{1}{c}{ Sumber Keragaman } & Nilai sig. \\
\hline BAHAN_AJAR & 0,000 \\
SEKOLAH & 0,000 \\
SEKOLAH * BAHAN_AJAR & 0,003 \\
\hline
\end{tabular}


Hasil analisis tersebut menunjukkan bahwa terdapat pengaruh yang signifikan dari bentuk bahan ajar yang digunakan, jenis sekolah, dan interaksi antara bentuk bahan ajar yang digunakan dan jenis sekolah terhadap peningkatan kemampuan menerapkan prinsip fluida dinamik siswa SMA/MA (gain score). Pengaruh dari perbedaan penggunaan bentuk bahan ajar dapat dilihat pada perbedaan antara rata-rata peningkatan skor tes (gain score) kelas eksperimen dan kelas kontrol (Tabel 13). Kelas eksperimen memiliki rata-rata gain score yang lebih besar daripada kelas kontrol, baik di SMAN 8 Yogyakarta maupun di MAN Laboratorium UIN Yogyakarta. Hal tersebut menunjukkan bahwa penggunaan handout bahan ajar yang dikembangkan menghasilkan peningkatan kemampuan menerapkan prinsip fluida dinamik siswa pada kedua sekolah tersebut yang lebih besar daripada penggunaan bahan ajar lain dalam penelitian ini.

Walapun demikian, pada tahapan ini, handout masih mengalami revisi. Kegiatan revisi pada tahap ini yaitu penggantian angka yang menyulitkan perhitungan pada contoh soal dan soal latihan, mengganti kunci jawaban soal latihan, dan memperbaiki pembahasan soal latihan dan tugas pada perangkat pendukung untuk pegangan guru fisika.

Hasil dari uji lapangan utama menunjukkan bahwa penggunaan handout bahan ajar fluida dinamik terintegrasi metakognisi menghasilkan peningkatan yang signifikan pada kemampuan siswa SMA dan MA dalam menerapkan prinsip fluida dinamik. Selain itu, siswa yang belajar dengan menggunakan handout tersebut mengalami peningkatan kemampuan menerapkan konsep fluida dinamik yang lebih tinggi daripada siswa yang tidak menggunakan handout tersebut. Berarti, handout bahan ajar fluida dinamik terintegrasi metakognisi telah siap digunakan pada uji lapangan operasional.

Tujuan uji lapangan operasional adalah untuk mengetahui apakah handout bahan ajar yang dikembangkan benar-benar telah siap digunakan di lapangan tanpa kehadiran pengembang. Uji lapangan operasional dilakukan di dua kelas siswa kelas XI IPA pada SMAN 8 Yogyakarta dengan menggunakan guru fisika pada kelas tersebut sebagai guru uji coba operasional. Hasil tabulasi dan analisis tanggapan guru fisika dan siswa SMA terhadap penggunaan handout bahan ajar fluida dinamik terintegrasi metakognisi disajikan dalam Tabel 18 dan Tabel 19.

Hasil tersebut menunjukkan bahwa handout bahan ajar yang dikembangkan sangat praktis penggunaannya menurut guru fisika SMA dan praktis penggunaannya menurut siswa SMA. Hal tersebut diakibatkan oleh komponenkomponennya yang mendukung praktikalitas penggunaan handout tersebut.

Kegiatan revisi pada tahap ini yaitu perbaikan tata kalimat dan tata bahasa, dan meringkas uraian materi. Setelah handout tersebut diperbaiki, diperoleh hasil akhir dari tahap uji lapangan operasional dalam penelitian dan pengembangan ini yaitu sebuah handout bahan ajar fluida dinamik terintegrasi metakognisi yang telah siap dipakai di lapangan.

Tabel 18. Hasil Tabulasi dan Analisis Tanggapan Guru Fisika SMA terhadap Penggunaan Handout Bahan Ajar Fluida Dinamik Terintegrasi Metakognisi.

\begin{tabular}{lcccc}
\hline \multicolumn{1}{c}{ Komponen } & Skor Total & $\begin{array}{c}\text { Skor } \\
\text { Rata-Rata }\end{array}$ & Persentase Keidealan & Kesimpulan \\
\hline kemudahan penggunaan handout & 38 & 38 & $95 \%$ & sangat mudah \\
kebermanfaatan handout & 58 & 58 & $90,63 \%$ & sangat bermanfaat \\
efisiensi waktu pembelajaran & 20 & 20 & $83,33 \%$ & sangat efisien \\
praktikalitas & $\mathbf{1 1 6}$ & $\mathbf{1 1 6}$ & $\mathbf{9 0 , 6 3 \%}$ & sangat praktis \\
\hline
\end{tabular}

Tabel 19. Hasil Tabulasi dan Analisis Tanggapan Siswa SMA terhadap Penggunaan Handout Bahan Ajar Fluida Dinamik Terintegrasi Metakognisi.

\begin{tabular}{lcccc}
\hline \multicolumn{1}{c}{ Komponen } & Skor Total & Skor Rata-Rata & Persentase Keidealan & Kesimpulan \\
\hline kemudahan penggunaan handout & 1207 & 26,82 & $67,06 \%$ & mudah \\
kebermanfaatan handout & 2012 & 44,72 & $69,86 \%$ & bermanfaat \\
efisiensi waktu pembelajaran & 721 & 16,02 & $66,76 \%$ & efisien \\
praktikalitas & $\mathbf{3 9 4 0}$ & $\mathbf{8 7 , 5 6}$ & $\mathbf{6 8 , 4 0} \%$ & praktis \\
\hline
\end{tabular}




\section{SIMPULAN DAN SARAN}

\section{Simpulan}

Berdasarkan hasil pengolahan data pada penelitian dan pengembangan ini, dapat disimpulkan bahwa handout fluida dinamik terintegrasi metakognisi yang dikembangkan memiliki kualitas yang sangat baik menurut penilaian ahli pendidikan fisika dan guru fisika SMA/MA serta berdasarkan hasil uji coba handout tersebut memiliki kualitas yang baik menurut tanggapan siswa SMA, penggunaan handout tersebut menghasilkan peningkatan kemampuan aplikatif prinsip fluida dinamik siswa kelas XI IPA pada SMAN 8 Yogyakarta dan MAN Laboratorium UIN Yogyakarta yang signifikan, handout tersebut penggunaannya sangat praktis menurut guru fisika SMA dan penggunaannya praktis menurut siswa SMA.

\section{Saran}

Berdasarkan hasil penelitian dan pengembangan ini, peneliti menyarankan agar handout bahan ajar fluida dinamik terintegrasi metakognisi hasil pengembangan digunakan sebagai salah satu alternatif bahan ajar dalam kegiatan pembelajaran fluida dinamik di SMA dan MA.

\section{DAFTAR PUSTAKA}

Akingbade, J. S., \& Omotade, A. A. (2013). Impact of metacognitive strategies of textbook reading on students' learning of physics in secondary schools. International Journal of Science and Research, 2(6). Retrieved from www.ijsr.net

Anandaraj, S., \& Ramesh, C. (2014). A study on the relationship between metacognition and problem solving ability of physics major students. Indian Journal of Applied Research, IV(V), 191-193. https://doi.org/10.15373/2249555X

Anderson, L. W., \& Krathwohl, D. R. (2010). Kerangka landasan untuk pembelajaran, pengajaran dan asesmen: Revisi taksonomi pendidikan Bloom (A. Prihant). Yogyakarta: Pustaka Pelajar. https://doi.org/2010

Campbell, J. (2007). Using metacogs to collaborate with students to improve teaching and learning in physics. Educational Insights, 11(2).

Coutinho, S. A. (2007). The relationship between goals, metacognition, and academic success. Educate: The Journal of Doctoral Research in Education, 7(1), 39-47. Retrieved from http://www.educatejournal.org/index.php/ educate/article/view/116

Departemen Pendidikan Nasional. (2008). Panduan pengembangan bahan ajar. Jakarta: Depdiknas.

Diniaty, A., \& Atun, S. (2015). Pengembangan lembar kerja peserta didik (LKPD) industri kecil kimia berorientasi kewirausahaan untuk SMK. Jurnal Inovasi Pendidikan IPA, I(1), 46. https://doi.org/10.21831/jipi.v1i1.4531

Direktorat Pembinaan SMA. (2010). Juknis penyusunan perangkat penilaian afektif di SMA. Jakarta: Kementerian Pendidikan dan Kebudayaan.

Flavell, J. H. (1979). Metacognition and cognitive monitoring: A new area of cognitive-developmental inquiry. American Psychologist, 34(10), 906-911. https://doi.org/10.1037/0003066X.34.10.906

Gall, M. D., Gall, J. P., \& Borg, W. R. (2007). Educational research: An introduction. Boston: Pearson/Allyn \& Bacon.

Ghasempour, Z., Bakar, M. N., \& Jahanshahloo, G. R. (2013). Innovation in teaching and learning through problem posing tasks and metacognitive strategies. International Journal of Pedagogical Innovatio, 1(1), 57-66. Retrieved from http://www.naturalspublishing.com/files/p ublished/2wh2o22kcq662p.pdf

Gok, T. (2010). The general assessment of problem solving processes in physics education. International Journal of Physics and Chemistry Education, 2(2), 110-122. https://doi.org/10.1007/s11409008-9026-0

Haiduc, L., \& Liliana, C. (2011). Reading science textbooks: The role of metacognition in reading comprehension. In 2011 International Conference on Languages, Literature and Linguistics (pp. 550-555). Singapore: IACSIT Press. Retrieved from http://www.ipedr.com/vol26/110-ICLLL 2011-L10197.pdf

Hake, R. R. (1998). Interactive-engagement versus traditional methods: A sixthousand-student survey of mechanics test 
data for introductory physics courses. American Journal of Physics, 66(1), 6474. https://doi.org/10.1119/1.18809

Inomiesa, E. A., Achufusi, N. N., \& Mgbemena, C. O. (2013). 'Effects of self-regulated learning and metacognitive learning cycle on the academic achievement of physics students. Open Journal of Advanced Engineering Techniques (OJAET), 1(3), $10-20$.

Prastowo, A. (2011). Panduan kreatif membuat bahan ajar inovatif. Jogjakarta: DIVA Press.

Scott, B., \& Levy, M. (2013). Metacognition: Examining the components of a fuzzy concept. Educational Research, 2(2), 120-131.

https://doi.org/10.5838/erej.2013.22.04

Shareeja, A. M. C., \& Gafoor, A. K. (2014). Does the use of metacognitive strategies influence students' problem solving skills in physics? IOSR Journal of Humanities and Social Science (IOSR-JHSS), 19(11), 48-51.

Shen, C.-Y., \& Liu, H.-C. (2011). Metacognitive skills development: A web-based approach in higher education. TOJET: The Turkish Online Journal of Educational Technology, 10(2), 140-150. Retrieved from http://www.tojet.net/articles/v10i2/10215. pdf

Snowman, J., \& McCown, R. (2011). Psychology applied to teaching. Nelson Education.

Veenman, M. V. J. (2012). Metacognition in science education: Defi nitions, constituents, and their intricate relation with cognition. In Metacognition in Science Education (pp. 21-36). Springer Netherlands. https://doi.org/10.1007/97894-007-2132-6

Woolfolk, A. (2007). Educational psychology. New York: Pearson Education, Inc. 